\title{
How Can Local Government Sustain a Terminated National Development Project?
} An Exit Strategy for the Techno Park Project in Tasikmalaya Regency, West Java, Indonesia

\author{
Satya Laksana ${ }^{1}$, Fityan Aonillah ${ }^{2}$, and Rubi Azhara ${ }^{3}$ \\ 1,2,3 Regional Development Planning Agency of Tasikmalaya Regency, Singaparna, Indonesia \\ satya_laksana@yahoo.com
}

\begin{abstract}
The sixth of nine Indonesian national development agendas under the President Joko Widodo administration is to increase productivity and competitiveness, one of which is by the establishment of Techno Parks. The projects will be terminated in 2019; however, exit strategies that contribute to sustainable development have been rarely considered throughout the history of development studies and practice. This paper examines the concept of exit strategies within the context of a case study of the Indonesian Institute of Sciences (LIPI)-assisted project of the Tasikmalaya Techno Park (TP) from 2015-2019. It addresses two questions: (1) How has LIPI executed the TP project in Tasikmalaya throughout the period? (2) What is the recommended exit strategy for regional policymakers after project termination? To overview the implementation of TP activities, an internal- external analysis was conducted, and to formulate exit strategies, SWOT and QSPM were employed. Data were collected from July-September 2018, consisting of primary data collected from competent respondents by semi-structured and in-depth interviews selected by the purposive sampling method as well as secondary data compiled from relevant institutions. The conclusion is that the Tasikmalaya TP has five core businesses and its mission is to become a center for dissemination, technology transfer, and agribusiness incubator. The TP was present in quadrant I, meaning that aggressive strategies were recommended. There were four future management options and independent management was considered as the most appropriate. Its role should be more supported by middle- to long-term strategies and a well prepared legal system. Policy implications are discussed.
\end{abstract}

Keywords: Exit Strategy, Regional Development, SWOT Analysis, Tasikmalaya District, Techno Park

ARTICLE INFO
Received: January 27, 2020
Received in revised form: March 26,2020
Accepted: April 30, 2020

Accepted: April 30, 2020

doi: https://doi.org/10.46456/jisdep.v1i1.9
JISDeP - The Journal of Indonesia Sustainable Development Planning Published by Centre for Planners' Development, Education, and Training (Pusbindiklatren), Ministry of National Development Planning/ National Development Planning Agency (Bappenas), Republic of Indonesia
Address: Jalan Proklamasi 70,

Central Jakarta, Indonesia 10320

Phone: +62 21 31928280/3192828

Fax: +622131928281

E-mail: pusbindiklatren@bappenas.go.id

Supported by Indonesian Development Planners

Association (PPPI) 


\section{Introduction}

The sixth of the 2014-2019 Indonesian national development agendas - called Nawacita (Sanskrit term, meaning nine goals) - under the President Joko Widodo administration is to increase productivity and competitiveness, one of which is by the establishment of Techno Parks (TPs) (Kusharsanto \& Pradita, 2016). TPs are incubators to encourage regional innovation and competitiveness in increasing the contributions of science and technology to economic development. TPs can also be media for creating a conducive environment for technopreneurship in local communities. The development of the Techno Parks supports the achievement of the Sustainable Development Goals (SDGs). The eighth goal of the SDGs is to promote sustained, inclusive, and sustainable economic growth, full and productive employment, and decent work for all.

As stated in the National Middle-Term Development Plan (Rencana Pembangunan Jangka Menengah Nasional/RPJMN) in 2015, the government had targeted to develop 100 TPs (Kusharsanto \& Praadita, 2016). However, over the period from 2015-2019, the National Government had only developed 22 Techno Parks across the country. The low number of TPs is due to limitations on many aspects such as funding, time, infrastructure, and urgent needs at each ministry or non-ministry government institution. The 22 TPs were established by three Ministries and four National Institutions. They are the Ministry of Industry/Kemenperin (5), Ministry of Research, Technology, and Higher Education/Kemenristek Dikti (4), Ministry of Agriculture/Kementan (1), National Nuclear Energy Agency/BATAN (4), Agency for Assessment and Application of Technology/BPPT (6), and Indonesian Institute of Sciences/LIPI (2). The projects had been developed at three levels: Science Techno Parks (STPS) at the national level, Science Parks (SPs) at the provincial level, and Techno Park (TPs) at the city or regency level (Asmara et al., 2018).

The Tasikmalaya TP is one of the TPs that had been developed by the Indonesian Institute of Sciences (LIPI) in 2015, as LIPI had been conducting many studies in the region for years, especially in the field of animal husbandry and dairy products. The project will be terminated in 2019 and the Techno Park will be acquired by the Local Government.

However, the exit strategy that contributes to sustainable development has been rarely considered throughout the history of development studies and practice. An exit strategy is important and critical as it is a specific plan describing how a program is intended to be withdrawn from a region while assuring that the achievement of development goals is not jeopardized and that further progress toward these goals is made. The goal is to assure sustainability of impacts and activities after the project has been withdrawn.

This paper examines the concept of exit strategies within the context of a case study of the LIPIassisted Tasikmalaya TP project from 2015-2019. It address two questions: (1) how the TP project in Tasikmalaya has been executed by LIPI throughout the period, and (2) what is the recommended exit strategy for regional policy makers after project termination. Moreover, it offers decisive perspectives on factors responsible for sustaining the project.

\section{Methodology}

To overview the implementation of Tasikmalaya TP activities, an internal-external analysis was conducted. In portraying the internal condition, Value chain analysis was utilized to explore the internal activities of a business in an effort to understand costs, to locate the activities that add the most value, and to differentiate from the competition (Porter, 2001). The VRIO method was also employed to identify and evaluate resources in the institution (Cardeal \& Antonio, 2012). In scrutinizing external circumstances, PEST analysis was utilized to identify significant changes in the Political, Economic, Social, and Technological landscapes (Gupta, A, 2013). Porter's five forces analysis was also utilized to identify and analyze the five competitive forces that shape a business and to determine its weaknesses and strengths (Porter, 2008).

Furthermore, in formulating exit strategies, SWOT analysis was utilized (Pickton \& Wright, 1998) within the Quantitative Strategic Planning Matrix (QSPM), which is employed for comparing feasible alternative actions (David, 2017). SWOT analysis provides the basic frame within which is performed analyses of decision situations (Kangas et al., 2003). It should lead to a balanced view of the technique and yield ideas for necessary theory building. (Helms \& Nixon, 2010). This analysis is the highest ranked set of tools or techniques of analysis used by firms in UK. (Glaister \& Falshaw, 1999). 


\subsection{Data Description}

The data as described in Table 1 were collected from July to September 2018, consisting of primary data collected from competent stakeholders and the regency government staff by semi-structured and deep interviews using the purposive sampling method. Secondary data were collected from relevant institutions, which are LIPI, the Regency Government Secretariat (Sekretariat Daerah), the Regional Development Planning Agency (Bappeda), the Department of Agriculture, Department of Industry and Trade, and the Department of Cooperatives and SMEs.

\begin{tabular}{|c|c|c|c|}
\hline Data & Type & Character & Technique \\
\hline \multicolumn{4}{|l|}{ PRELIMINARY DATA } \\
\hline $\begin{array}{l}\text { Vision, mission, and general condition } \\
\text { of the Tasikmalaya TP } \\
\text { INTERNAL ACTIVITIES }\end{array}$ & Secondary & Qualitative & Literature study \\
\hline $\begin{array}{l}\text { Material procurement \& technology } \\
\text { provision }\end{array}$ & Primary & Qualitative & In-depth interview \\
\hline Product \& product processing & Primary & Qualitative & In-depth interview \\
\hline Marketing process & Primary & Qualitative & In-depth interview \\
\hline Customer service & Primary & Qualitative & In-depth interview \\
\hline $\begin{array}{l}\text { Human resources \& administrative } \\
\text { service }\end{array}$ & Primary & Qualitative & In-depth interview \\
\hline \multicolumn{4}{|l|}{ RESOURCE OR CAPABILITY } \\
\hline Value & Primary & Qualitative & Semi-structured question \\
\hline Rareness & Primary & Qualitative & Semi-structured question \\
\hline Inimitability & Primary & Qualitative & Semi-structured question \\
\hline $\begin{array}{l}\text { Organization } \\
\text { ENVIRONMENTAL SHAPE }\end{array}$ & Primary & Qualitative & Semi-structured question \\
\hline Political landscape & Primary \& Secondary & Qualitative & Interview \& Literature study \\
\hline Economic landscape & Primary \& Secondary & Qualitative & Interview \& Literature study \\
\hline Social landscape & Primary \& Secondary & Qualitative & Interview \& Literature study \\
\hline $\begin{array}{l}\text { Technological landscape } \\
\text { COMPETITIVE SOURCE }\end{array}$ & Primary \& Secondary & Qualitative & Interview \& Literature study \\
\hline Competitive rivalry & Primary \& Secondary & Qualitative & Interview \& Literature study \\
\hline Threat of new entrants & Primary \& Secondary & Qualitative & Interview \& Literature study \\
\hline Supply power & Primary \& Secondary & Qualitative & Interview \& Literature study \\
\hline Buyer power & Primary \& Secondary & Qualitative & Interview \& Literature study \\
\hline Threat of substitution & Primary \& Secondary & Qualitative & Interview \& Literature study \\
\hline
\end{tabular}

\subsection{Designs}

The logical framework in this paper is depicted in Figure 1, showing the research flowchart with the methods and instruments used at each stage. The first step was the identification of the vision, mission, and policies of the Tasikmalaya TP as the research background and problem statement, which were obtained by a series of literature studies, observations, and interviews. The second step was internal assessment by using the Supply Value Chain method to identify the main activities of the Tasikmalaya TP based on the product and service processing stages. This step was carried out by in-depth interviews with the Tasikmalaya TP employees and LIPI liaison officers. Furthermore, with the questionnaire instrument that had been tested for validity and reliability, semi-structured interviews were conducted to identify internal strengths and weaknesses in running the business cycle by the weighting aspects of Value, Rareness, Imitability, and Organization (the VRIO method).

The next step was external assessment by conducting PEST analysis to capture the political, economic, social, and technological outlooks that shape the business climate. By performing similar data collection to the internal assessment process, the next phase was Porter's five forces analysis to determine external opportunities and threats. The quadrant position of Tasikmalaya TP was defined by the intersection of the calculated Total Weighted Internal Factors Evaluation (IFE) and Total Weighted External Factors Evaluation (EFE). The results were discussed in a Focus Group Discussion (FGD) to conduct SWOT analysis in order to design alternatives of exit strategies.

The last step was calculating the Total Attractive Scores (TAS) to obtain a Quantitative Strategic Planning Matrix (QSPM) for evaluating Tasikmalaya TP exit strategy options for LIPI post-management assistance. 


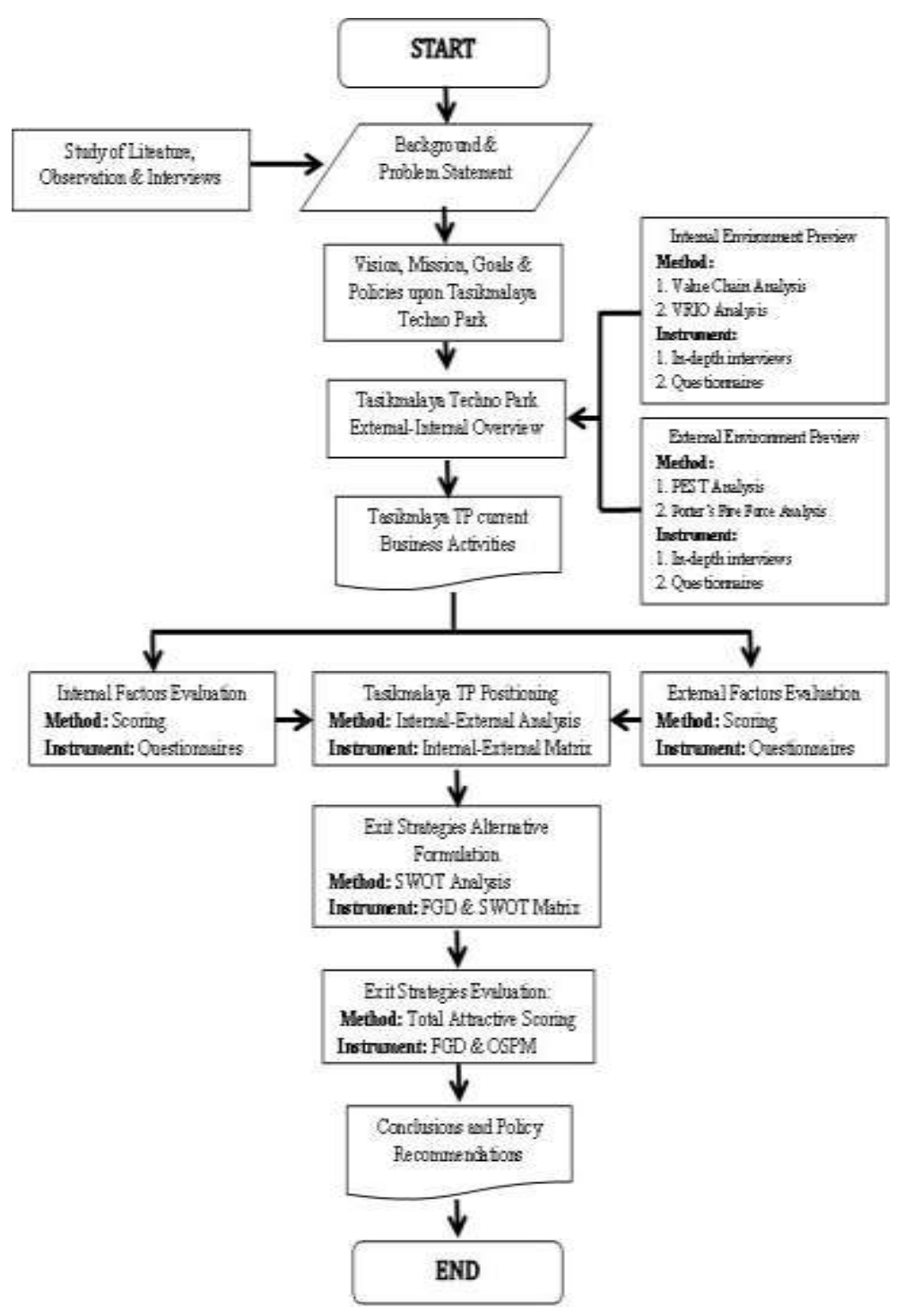

Figure 1. Design and Logical Framework Source: Research Design

\subsection{Procedures}

In this study, primary data were collected by interviews while secondary data were obtained by literature studies. Preliminary data were used for the background of the study and the following analysis. Data of internal activities for the supply value chain analysis and Resource or Capability data for the VRIO analysis were integrated into a matrix, as represented in Table 2, by yes/no questions in order to define the competitive implication of each resource or capability. Further, economic performance and SWOT categories were pulled out into the Internal Overview Matrix.

\begin{tabular}{|c|c|c|c|c|c|c|c|c|}
\hline Resources or Capability & $\mathbf{V}$ & $\mathbf{R}$ & I & $\mathbf{O}$ & $\begin{array}{l}\text { Competitive } \\
\text { Implications }\end{array}$ & $\begin{array}{l}\text { Economic } \\
\text { Performance }\end{array}$ & $\begin{array}{l}\text { SWOT } \\
\text { Category }\end{array}$ & \\
\hline \multicolumn{9}{|c|}{ Material Procurement \& Technology Provision } \\
\hline $\begin{array}{l}\text { Convinent technology } \\
\text { used }\end{array}$ & Yes & No & - & - & Competitive Parity & Normal & $\begin{array}{l}\text { Strength } \\
\text { weakness }\end{array}$ & or \\
\hline $\begin{array}{l}\text { Complete } \quad \text { produc } \\
\text { equipment }\end{array}$ & Yes & No & - & - & Competitive Parity & Normal & $\begin{array}{l}\text { Strength } \\
\text { weakness }\end{array}$ & or \\
\hline Handily raw materials & Yes & No & - & - & Competitive Parity & Normal & $\begin{array}{l}\text { Strength } \\
\text { weakness }\end{array}$ & or \\
\hline $\begin{array}{l}\text { Easy } \\
\text { maintenance }\end{array}$ & Yes & No & - & - & Competitive Parity & Normal & $\begin{array}{l}\text { Strength } \\
\text { weakness }\end{array}$ & or \\
\hline
\end{tabular}




\begin{tabular}{|c|c|c|c|c|c|c|c|}
\hline Resources or Capability & V & $\mathbf{R}$ & I & 0 & $\begin{array}{l}\text { Competitive } \\
\text { Implications }\end{array}$ & $\begin{array}{l}\text { Economic } \\
\text { Performance }\end{array}$ & $\begin{array}{l}\text { SWOT } \\
\text { Category }\end{array}$ \\
\hline Production & Yes & Yes & Yes & Yes & $\begin{array}{l}\text { Sustained } \\
\text { Competitive } \\
\text { Advantage }\end{array}$ & Above normal & $\begin{array}{l}\text { Strength } \\
\text { long-term } \\
\text { competence }\end{array}$ \\
\hline \multicolumn{8}{|c|}{ Product \& Product Processing } \\
\hline Good quality products* & Yes & Yes & No & - & $\begin{array}{l}\text { Temporary } \\
\text { Competitive } \\
\text { Advantage }\end{array}$ & Above Normal & $\begin{array}{l}\text { Strength and } \\
\text { Special } \\
\text { Competence }\end{array}$ \\
\hline Un-copyright brands & No & No & No & No & $\begin{array}{l}\text { Competitive } \\
\text { disadvantage }\end{array}$ & Below Normal & Weakness \\
\hline Good packaging & Yes & No & - & - & Competitive Parity & Normal & $\begin{array}{l}\text { Strength } \\
\text { sweakness }\end{array}$ \\
\hline Un-sertified ${ }^{\star \star}$ products & No & No & No & No & $\begin{array}{l}\text { Competitive } \\
\text { disadvantage }\end{array}$ & Below Normal & Weakness \\
\hline Local raw materials & Yes & No & - & $\begin{array}{l}\text { Yes/ } \\
\text { No }\end{array}$ & Competitive Parity & Normal & $\begin{array}{l}\text { Strength } \\
\text { sweakness }\end{array}$ \\
\hline \multicolumn{8}{|l|}{ Marketing } \\
\hline Domestic \& local market & Yes & No & - & - & Competitive Parity & Normal & $\begin{array}{l}\text { Strength or } \\
\text { sweakness }\end{array}$ \\
\hline $\begin{array}{l}\text { Generic customer, no } \\
\text { segmentation }\end{array}$ & Yes & Yes & No & - & $\begin{array}{l}\text { Temporary } \\
\text { Competitive } \\
\text { Advantage }\end{array}$ & Above Normal & $\begin{array}{l}\text { Strength and } \\
\text { Special } \\
\text { Competence }\end{array}$ \\
\hline intermittent customer care & No & No & No & No & $\begin{array}{l}\text { Competitive } \\
\text { disadvantage }\end{array}$ & Below Normal & Weakness \\
\hline Competitive selling price & Yes & Yes & Yes & Yes & $\begin{array}{l}\text { Sustained } \\
\text { Competitive } \\
\text { Advantage }\end{array}$ & Above normal & $\begin{array}{l}\text { Strength } \\
\text { long-term } \\
\text { competence }\end{array}$ \\
\hline $\begin{array}{l}\text { Costumer Service } \\
\text { as agrobusiness Incubator }\end{array}$ & Yes & Yes & Yes & Yes & $\begin{array}{l}\text { Sustained } \\
\text { Competitive } \\
\text { Advantage }\end{array}$ & Above normal & $\begin{array}{l}\text { Strength } \\
\text { long-term } \\
\text { competence }\end{array}$ \\
\hline Insufficient infrastructure & No & No & No & No & $\begin{array}{l}\text { Competitive } \\
\text { disadvantage }\end{array}$ & Below Normal & Weakness \\
\hline Limited tenant & No & No & No & No & $\begin{array}{l}\text { Competitive } \\
\text { disadvantage }\end{array}$ & Below Normal & Weakness \\
\hline $\begin{array}{l}\text { Little local government } \\
\text { support } \\
\text { Human Resources \& Admin }\end{array}$ & $\begin{array}{l}\text { No } \\
\text { stration }\end{array}$ & $\begin{array}{l}\text { No } \\
\text { service }\end{array}$ & No & No & $\begin{array}{l}\text { Competitive } \\
\text { disadvantage }\end{array}$ & Below Normal & Weakness \\
\hline Experienced researchers & Yes & Yes & Yes & Yes & $\begin{array}{l}\text { Sustained } \\
\text { Competitive } \\
\text { Advantage }\end{array}$ & Above normal & $\begin{array}{l}\text { Strength \& } \\
\text { long-term } \\
\text { competence }\end{array}$ \\
\hline $\begin{array}{l}\text { Non-permanent } \\
\text { officer }\end{array}$ & Yes & No & - & - & Competitive Parity & Normal & $\begin{array}{l}\text { Strength or } \\
\text { sweakness }\end{array}$ \\
\hline
\end{tabular}

By using the questionnaire that had been tested for validity and reliability, the environmental shape data for PEST analysis were assessed to define the degree of importance. Likewise, the competitive force data for Porter's five forces analysis were rated by their degree of power. The two analyses were then summarized into the External Overview Matrix. The next step was Internal and External Factor Evaluation to conduct SWOT analysis in a Focus Group Discussion (FGD). In the FGD, there were debates on exit strategy formulation. In the end, the exit strategy options were rated by their total attractive scores and each future management option was compared by the aspects of legal bases, expenditure, revenue, debts, and investment.

\section{Results and Discussion}

The Tasikmalaya TP was developed by LIPI through the Biology Research Center in 2015. Built on 3.5 hectares of land provided by the regency government, it runs five core businesses: 1) an agribusiness training center, 2) organic farming research and development (specifically pilot organic vegetable and mushroom cultivation, and organic fertilizer production and laboratory), 3) a pilot dairy product center, 4) an agroforestry development center, and 5) a pilot post-harvest center (including product branding and packaging).

Organized by a coordinator, eight researchers, and three administrative staff, and supported financially by 9.5 billion IDR from the regency government budget, the Tasikmalaya TP operates a green house, a post-harvest building, a mushroom production plant, a fertilizer laboratory, a cowshed, a milk 
processing plant, a training center, and a fully furnished office. Its mission is to become a center for dissemination, technology transfer, and agribusiness incubator.

\subsection{Internal Overview}

In running its business, based on value chain analysis, the identified main activities of Tasikmalaya TP are material procurement \& technology provision, product processing, marketing, and customer or client services. With the subsequent VRIO method, the six elements of strengths and weaknesses were determined in Table 3.

Table 3 implies that as a leading institution in science and technology, LIPI can develop the Tasikmalaya TP as an agribusiness incubator equipped with exhaustive and applicable technology. Supported by abundant local resources for provision of raw materials, the TP can produce good quality products at competitive selling prices.

Table 3: Overview of Internal Strengths and Weakness

\begin{tabular}{llll}
\hline No & Strengths & No & Weaknesses \\
\hline 1 & Agribusiness Incubator & 1 & Insufficient infrastructure \\
2 & Complete and easy maintenance of equipment & 2 & Little local government support \\
3 & Usage of convenient technology & 3 & Non-permanent field officers \\
4 & Local raw materials & 4 & Intermittent customer care \\
5 & Good-quality products & 5 & Non-certified products \\
6 & Competitive selling prices & 6 & Limited tenants \\
\hline Source: Data Analysis &
\end{tabular}

Despite those strong points, there were still weak points, encompassing stagnant infrastructure provision and little government support that lead to insufficient infrastructure, non-certified products (Indonesian National Standard/SNI \& halal certification), and limited tenants. In the human resource aspect, Tasikmalaya TP still employs non-permanent officers that leads to suboptimal marketing and poor customer care. Those strengths and weaknesses were then evaluated by a scoring method to result in an Internal Factors Evaluation (IFE) Matrix as presented in Table 4. It was discovered that the usage of convenient technology applied was the greatest strength, while infrastructure condition was the greatest weakness.

\begin{tabular}{|c|c|c|c|c|}
\hline No & Internal Factors & Weight & Rating & Score \\
\hline & STRENGTHS & & & \\
\hline 1 & Usage of convenient technology & 0.098 & 3.634 & 0.358 \\
\hline 2 & Complete and easy maintenance of equipment & 0.091 & 3.634 & 0.330 \\
\hline 3 & Local raw materials & 0.088 & 2.884 & 0.255 \\
\hline 4 & Good-quality products & 0.092 & 3.634 & 0.335 \\
\hline 5 & Agribusiness incubator & 0.093 & 2.884 & 0.270 \\
\hline \multirow[t]{2}{*}{6} & Competitive selling prices & 0.082 & 3.000 & 0.246 \\
\hline & WEAKNESSES & & & \\
\hline 1 & Insufficient infrastructure & 0.080 & 2.884 & 0.229 \\
\hline 2 & Little local government support & 0.080 & 2.289 & 0.195 \\
\hline 3 & Limited tenants & 0.074 & 2.621 & 0.195 \\
\hline 4 & Non-certified products & 0.073 & 2.080 & 0.152 \\
\hline 5 & Non-permanent field officers & 0.069 & 2.000 & 0.139 \\
\hline 6 & Intermittent customer care & 0.078 & 1.587 & 0.124 \\
\hline
\end{tabular}

Source: Data Analysis

\subsection{External Overview}

The need to address societal issues within market activities pressures organizations to incorporate the social environment as an operational variable (Krzyżanowska \& Tkaczyk, 2015). The external shape of Tasikmalaya TP encompasses political, economic, social, and technological environments. As described in Table 4, both the national and local governments have political will in TP development, which is shown by the signing of a Memorandum of Understanding (MoU) between LIPI and the Tasikmalaya Regency Government for Tasikmalaya TP management. However, political uncertainties at the national, regional, and local levels lead to a discontinuous development policy. 
In the perspective of economics, Tasikmalaya Regency provides supporting natural resources for the TP business, but on the other hand, competition for high-quality raw materials and strict selling prices takes place. The data shows that annual market share increased gradually due to the large population, but the customer characteristic tends to be of a low product loyalty. The characteristic of the local community is that there is native entrepreneurship that on one hand can endorse the TP business, but on the other hand can create competition for product innovation and marketing.

Geographically, the Tasikmalaya TP has a strategic position as it is near to an agricultural zone (natural resources), having the advantage of bordering the City of Tasikmalaya as a market and East Parahyangan as a center of trading and economic activities. The geographic position can also be a disadvantage as it leads to easy availability of substitute products from competitors. Other identified opportunities and threats were availability of advanced technologies as a supporting factor and land degradation or conversion as a threat to business sustainability.

Table 5: Overview of External Opportunities and Threats

\begin{tabular}{|c|c|c|c|}
\hline No & Opportunities & No & Threats \\
\hline 1 & $\begin{array}{l}\text { MoU between LIPI and Tasikmalaya Government } \\
\text { for Tasikmalaya Techno Park Management }\end{array}$ & 1 & $\begin{array}{l}\text { Discontinuous development policy due to political } \\
\text { uncertainty }\end{array}$ \\
\hline 2 & Natural resources supporting agribusiness & 2 & $\begin{array}{l}\text { Competition for high-quality raw materials and } \\
\text { strict } \\
\text { selling prices }\end{array}$ \\
\hline 3 & Annual increase of market share & 3 & Low customer loyalty \\
\hline 4 & Local community entrepreneurship & 4 & Competition for product innovation and marketing \\
\hline 5 & Strategic location & 5 & Easy availability of substitute products \\
\hline 6 & Technology and innovation availability & 6 & Land degradation and land conversion \\
\hline
\end{tabular}

Source: Data Analysis

By using a scoring method to evaluate external opportunities and threats, the result was the External Factors Evaluation (EFE) Matrix as in Table 6. It was determined that the highest scores were for political aspects for both opportunities and threats, while the lowest were for economic aspects.

\begin{tabular}{|c|c|c|c|c|}
\hline No & External Factors & Weight & Rating & Score \\
\hline & OPPORTUNITIES & & & \\
\hline 1 & $\begin{array}{l}\text { MoU between LIPI and Tasikmalaya Government for } \\
\text { Tasikmalaya Techno Park Management }\end{array}$ & 0.096 & 3.302 & 0.317 \\
\hline 2 & Natural resources supporting agribusiness & 0.090 & 2.884 & 0.259 \\
\hline 3 & Strategic location & 0.093 & 3.000 & 0.280 \\
\hline 4 & Technology and innovation availability & 0.110 & 3.634 & 0.399 \\
\hline 5 & Annual increase of market share & 0.086 & 2.621 & 0.225 \\
\hline 6 & $\begin{array}{l}\text { Local community entrepreneurship } \\
\text { THREATS }\end{array}$ & 0.092 & 2.621 & 0.242 \\
\hline 1 & $\begin{array}{l}\text { Discontinuous development policy due to political } \\
\text { uncertainty }\end{array}$ & 0.087 & 1.587 & 0.138 \\
\hline 2 & Land degradation and land conversion & 0.062 & 1.817 & 0.112 \\
\hline 3 & Competition for product innovation and marketing & 0.086 & 1.817 & 0.156 \\
\hline 4 & Competition for raw materials and strict selling prices & 0.087 & 2.000 & 0.157 \\
\hline 5 & Easy availability of substitute products & 0.058 & 1.260 & 0.073 \\
\hline 6 & Low customer loyalty & 0.62 & 1.000 & 0.062 \\
\hline
\end{tabular}

Source: Data Analysis

\subsection{Tasikmalaya TP Positioning}

The IFE Matrix (Table 4) and EFE Matrix (Table 6) were combined to define the positioning of the Tasikmalaya TP. It was found that the TP is present in quadrant I with an internal strength score of 2.816 and opportunity score of 2.420 , implying that S-O or aggressive strategies are the most appropriate, as shown in Figure 2. 


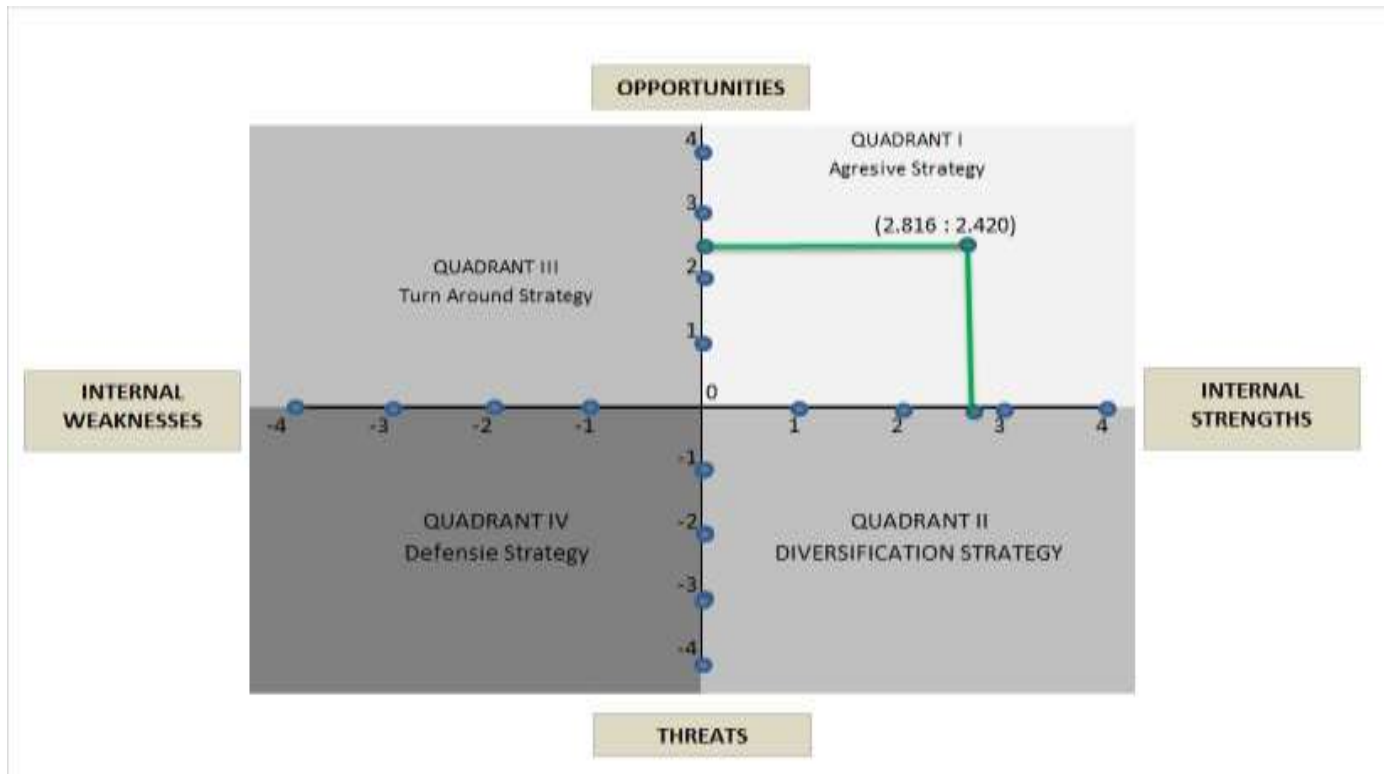

The IFE total weight score (2.816) signifies that Tasikmalaya TP has an average internal strength; likewise, the EFE total weight score (2.420) is a sign that there are medium external opportunities that shape the TP environment. The intersection of those scores places Tasikmalaya TP in cell V, pointing to hold-and-maintain strategies as the most appropriate for future development. Figure 3 shows the further positioning of the Tasikmalaya TP, delineating specific proper strategies such as market penetration and product development. The subsequent definition of the proper strategy for future TP development, exit strategy formulation, and evaluation for future Tasikmalaya TP operators are elaborated in the following subsection.

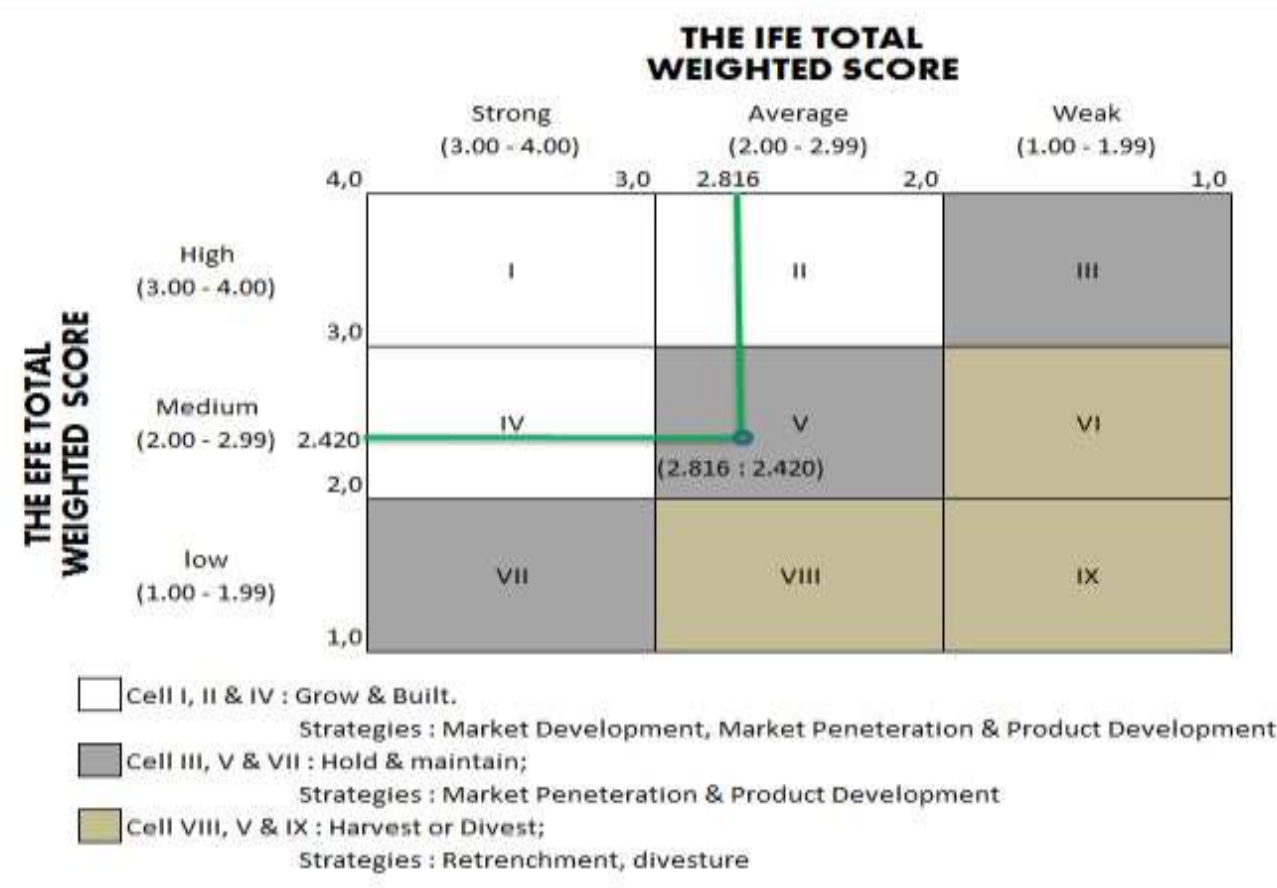

\subsection{Exit Strategy Formulation}

In formulating a suitable exit strategy, a long list of strategy options were discussed by competent stakeholders in a Focus Group Discussion. The SWOT analysis matrix as displayed in Table 7 combines Table 4 and Table 6 in order to address S-O, W-O, S-T, and W-T strategies. 
Table 7: SWOT Analysis Matrix

\begin{tabular}{|c|c|c|}
\hline & STRENGTHS & WEAKNESSES \\
\hline EXTERNAL FACTORS & $\begin{array}{l}\text { S1. Convinient technology used } \\
\text { S2. Complete and easy maintenance of } \\
\text { equipment } \\
\text { S3. Local raw materials } \\
\text { S. } 4 \text { Good quality products } \\
\text { S.5 as agribusiness Incubator } \\
\text { S.6 Competitive selling prices }\end{array}$ & $\begin{array}{l}\text { W.1 Insufficient infrastructure } \\
\text { W.2 Little local government } \\
\text { support } \\
\text { W.3 Limited tenant } \\
\text { W.4 Un-certified products } \\
\text { W.5 Non-permanent field officer } \\
\text { W.6 intermittent customer care }\end{array}$ \\
\hline OPPORTUNITIES & S-O STRATEGIES & W-O STRATEGIES \\
\hline $\begin{array}{lcr}\text { O.1 MOU } & \text { between LIPI } & \text { and } \\
\text { Tasikmalaya } & \text { Government } & \text { upon } \\
\text { Tasikmalaya } & \text { Techno } & \text { Park } \\
\text { Management } & & \end{array}$ & $\begin{array}{l}\text { Implementation of } \mathrm{MOU} \text { as the } \\
\text { government support }(\mathrm{S} 1, \mathrm{O} 1)\end{array}$ & $\begin{array}{l}\text { Infrastructures provision and } \\
\text { maintenance }(\mathrm{W} 1, \mathrm{O} 1)\end{array}$ \\
\hline $\begin{array}{l}0.2 \text { natural resources supporting } \\
\text { agriculture }\end{array}$ & $\begin{array}{l}\text { Good Agriculture Practise (GAP) } \\
\text { Implementation from on-farm to off-farm } \\
(\mathrm{S} 1, \mathrm{O} 2)\end{array}$ & $\begin{array}{l}\text { Local government programs } \\
\text { corresponding with TP activities } \\
\text { (W2, O2) }\end{array}$ \\
\hline 0.3 strategic location & $\begin{array}{l}\text { Agro-tourism \& } \quad \text { edu-tourism } \\
\text { development }(\mathrm{S} 4, \mathrm{O} 3)\end{array}$ & $\begin{array}{l}\text { independent and professional } \\
\text { management formation (W2, O1) }\end{array}$ \\
\hline $\begin{array}{l}0.4 \text { Technology and innovation } \\
\text { availability }\end{array}$ & $\begin{array}{l}\text { Agribusiness incubator revitalization } \\
(\mathrm{S} 5, \mathrm{O} 4)\end{array}$ & $\begin{array}{l}\text { Business partnership with private } \\
\text { sector / business actors for } \\
\text { investment and market } \\
\text { development }(\mathrm{W} 3, \mathrm{O} 3)\end{array}$ \\
\hline O.5 Annual increase of market share & Intensive promotion (S4, O5) & \\
\hline $\begin{array}{l}\text { O.6 Local } \quad \text { community } \\
\text { entrepreneurship }\end{array}$ & $\begin{array}{l}\text { Agribusiness training } \quad \text { centre } \\
\text { revitalization }(\mathrm{S} 6, \mathrm{O})\end{array}$ & \\
\hline THREATS & S-T STRATEGIES & W - T STRATEGIES \\
\hline $\begin{array}{l}\text { T.1 Discontinuous development } \\
\text { policy due to political uncertainty }\end{array}$ & $\begin{array}{l}\text { Partnership with research institutions for } \\
\text { applied technology invention and } \\
\text { dissemination (S3, T1) }\end{array}$ & Intensive promotion (W6, T4) \\
\hline $\begin{array}{l}\text { T.2 land degradation and land } \\
\text { conversion }\end{array}$ & $\begin{array}{l}\text { Partnership with research institutions for } \\
\text { applied technology invention and } \\
\text { dissemination (S3, T2) }\end{array}$ & $\begin{array}{l}\text { Sustainable, ecological and } \\
\text { professional } \\
(\mathrm{W} 5, \mathrm{~T} 2)\end{array}$ \\
\hline $\begin{array}{l}\text { T.3 Competition for product } \\
\text { innovation and marketing }\end{array}$ & $\begin{array}{l}\text { Partnership with research institutions for } \\
\text { applied technology invention and } \\
\text { dissemination (S3, T3) }\end{array}$ & $\begin{array}{l}\text { Providing roadmap and business } \\
\text { plans }(\mathrm{W} 3, \mathrm{~T} 1)\end{array}$ \\
\hline $\begin{array}{l}\text { T.4 Competition for raw materials and } \\
\text { strict selling price competition }\end{array}$ & $\begin{array}{l}\text { Partnership with local communities } \\
(\mathrm{S} 3, \mathrm{~T} 4)\end{array}$ & $\begin{array}{l}\text { Segmenting and differentiating } \\
\text { products }(\mathrm{W} 6, \mathrm{~T} 5)\end{array}$ \\
\hline T.5 Ease for substitute products & Intensive Promotion $(\mathrm{S} 4, \mathrm{~T} 5)$ & $\begin{array}{l}\text { independent and professional } \\
\text { management formation (W2,T1) }\end{array}$ \\
\hline T.6 Low costumer loyalty & customer service improvement $(\mathrm{S} 5, \mathrm{~T} 6)$ & \\
\hline
\end{tabular}

Source: FGD 2018

Next, the long list of strategies in Table 7 were then separated into Generic Strategy Tiers to shorten the list in order to formulate the appropriate exit strategy. Table 8 clusters the strategy formula defined in the SWOT analysis matrix into the three categories of corporation strategy, business strategy, and functional strategy.

Table 8: Exit Strategy Formulation

\begin{tabular}{|c|c|}
\hline Generic Strategy Tiers & Strategy Formulation \\
\hline $\begin{array}{l}\text { Foreward \& Backward Integration } \\
\text { Market Penetration } \\
\text { Market Development } \\
\text { Lead overrall cost } \\
\text { Producting and operating strategy }\end{array}$ & $\begin{array}{l}\text { Good Agriculture Practise (GAP) Implementation from on-farm to } \\
\text { off-farm (S1, O2) } \\
\text { Intensive Promotion (S4,O5). (S4, T5), (W6, T4) } \\
\text { Agro-tourism \& edu-tourism development (S4, O3) Agrobusiness } \\
\text { incubator revitalization (S5, O4) } \\
\text { Partnership with research institutions for applied technology } \\
\text { invention and dissemination (S3, T3) } \\
\text { Segmenting and differentiating products (W6,T5) } \\
\text { Partnership with local communities (S3,T4) } \\
\text { Infasturucters provision and maintenance (W1, O1) } \\
\text { Implementation of MoU as the government support (S1, O1) } \\
\text { Providing roadmap and business plans (W3,T1) } \\
\text { independent and professional management formation (W2, O1) } \\
\text { independent and professional management formation (W2,T1) } \\
\text { Sustainable, ecological and professional management (W5,T2) }\end{array}$ \\
\hline
\end{tabular}

Source: FGD 2018

Enright (2001) found that small enterprises usually utilized intuitive approaches in both market orientation and product development. Traditional concepts of sales management, account management, and customer service are being overtaken by initiatives such as customer business development, strategic 
sales organization, and strategic customer management (Piercy \& Lane, 2009) Greenly (1994) highlights the dichotomy between strategic planning as a determinant of performance and strategic planning as a process to improve the effectiveness of management. This study used scientific approaches in order to define a more proper strategy option.

\subsection{Exit Strategy Evaluation}

In the Focus Group Discussion, four options were obtained regarding the future of Tasikmalaya TP management, differentiated among aspects of legal bases, revenue, expenditure, debts, and investment. The first option is that the Tasikmalaya TP would be operated by a Local Government Institution (Organisasi Perangkat Daerah/OPD). The TP may be operated by the Department of Agriculture (Dinas Pertanian), or the Department of Industry and Trade (Dinas Perindustrian dan Perdagangan). Inclusion of TP activities as a part of an OPD functions requires local parliament legalization by a Regional Regulation as the legal basis. In this setting, the Tasikmalaya TP would be a part of public service. An OPD will never be locked out of capital as it utilizes the government budget for initial capital and business operations. However, this option would result in the least independent management, as expenditures would be limited by a strict and rigid government budget and investment for business development will never occur.

Another option would be to become a public service agency (Badan Layanan Umum/BLU). A BLU is an ad hoc government institution that is formed to provide public goods or services based on the principles of efficiency and productivity without being profit-oriented. A BLU is more professional than an OPD in terms of service delivery and management but still demands government budget for operations, and expenditures must adhere to government rules. A BLU can be established by a Regent Decree without approval from the Local Parliament. The hybrid management model is another alternative exit strategy for the Tasikmalaya TP similar to a BLU but is more business-oriented, as the expenditures are based on business calculations. However, some government employees are still required to be present in the board of directors.

The last choice is to become a Regionally-Owned Enterprise (Badan Usaha Milik Daerah/BUMD), which is the most independent institution compared to the others as it applies business calculations for the aspects of revenue, expenditures, debts, and investment. However, a BUMD needs a well-prepared business plan and local parliament approval for establishment. Table 9 elaborates the four alternative circumstances that were discussed in the FGD.

Table 9: Forthcoming Tasikmaya Management Comparison Matrix

\begin{tabular}{|c|c|c|c|c|}
\hline Aspects & $\begin{array}{l}\text { Local Government } \\
\text { Institution (OPD) }\end{array}$ & $\begin{array}{l}\text { Public Service Agency } \\
\text { (BLU) }\end{array}$ & $\begin{array}{l}\text { Hybrid Management } \\
\text { Model }\end{array}$ & $\begin{array}{l}\text { Regional-State-Owned } \\
\text { Enterprise (BUMD) }\end{array}$ \\
\hline \multirow[t]{4}{*}{ Legal bases } & $\begin{array}{ll}\text { The } & \text { Regional } \\
\text { Requlation } & \end{array}$ & The Regent's Decree & The Regent's Decree & $\begin{array}{ll}\text { The } & \text { Regional } \\
\text { Requlation } & \end{array}$ \\
\hline & $\begin{array}{l}\text { As the Regional } \\
\text { Government Income }\end{array}$ & As business income & As business income & As business income \\
\hline & $\begin{array}{l}\text { Government budget } \\
\text { as an investment (not } \\
\text { a revenue) }\end{array}$ & $\begin{array}{l}\text { Government budget as } \\
\text { a revenue }\end{array}$ & $\begin{array}{l}\text { Government budget as } \\
\text { a revenue }\end{array}$ & $\begin{array}{l}\text { Government budget as } \\
\text { an equity capital }\end{array}$ \\
\hline & $\begin{array}{l}\text { Government budget is } \\
\text { mandatory }\end{array}$ & $\begin{array}{l}\text { Government budget is } \\
\text { demanded }\end{array}$ & $\begin{array}{l}\text { Government budget } \\
\text { could be an one an } \\
\text { income sources }\end{array}$ & $\begin{array}{l}\text { Government budget is } \\
\text { not conditional }\end{array}$ \\
\hline Expenditure & $\begin{array}{l}\text { Based on ceiling } \\
\text { budget }\end{array}$ & $\begin{array}{l}\text { May exceed the ceiling } \\
\text { budget (conditional) }\end{array}$ & $\begin{array}{l}\text { Based on business } \\
\text { calculation }\end{array}$ & $\begin{array}{l}\text { Based on business } \\
\text { calculation }\end{array}$ \\
\hline Debts & May not be in a debt & $\begin{array}{l}\text { May be in a long-term } \\
\text { dept on the Regent's } \\
\text { endorsement }\end{array}$ & & $\begin{array}{l}\text { Based on } \\
\text { calculation }\end{array}$ \\
\hline Investment & $\begin{array}{l}\text { Prohibited } \\
\text { investing }\end{array}$ & $\begin{array}{l}\text { May perform a long- } \\
\text { term investment on the } \\
\text { Regent's endorsement }\end{array}$ & $\begin{array}{l}\text { May perform a long- } \\
\text { term investment on the } \\
\text { Regent's endorsement }\end{array}$ & $\begin{array}{l}\text { Based on business } \\
\text { calculation }\end{array}$ \\
\hline
\end{tabular}

Source: FGD 2018

Based on the organization characteristics in Table 9, it is implied that the management options closer to the right side of the table indicate a more independent and more professional organization.

In addition to the qualitative approach, the FGD also employed a quantitative method to measure the appropriateness of strategy options. The Total Attractive Score (TAS) of each strategy is provided in a Quantitative Strategic Planning Matrix (QSPM), which is shown in Table 10. 
Table 10: Quantitative Strategic Planning Matrix

\begin{tabular}{lll}
\hline No & Strategy option & Total Attractive Score \\
\hline 1 & independent and professional management formation (W2, O1) (W2,T1) & 7.19 \\
2 & Sustainable, ecological and professional management (W5, T2) & 7.17 \\
3 & Providing roadmap and business plans (W3,T1) & 6.81 \\
4 & Intensive Promotion (S4,O5). (S4, T5), (W6, T4) & 6.77 \\
5 & Implementation of MoU as the government support (S1, O1) & 6.24 \\
6 & Infasturucters provision and maintenance (W1, O1) & 6.12 \\
7 & Local government programs corresponding with TP activities (W2, O2) & 5.98 \\
8 & Partnership with research institutions for applied technology invention & 5.94 \\
9 & dissemination (S3, T1), (S3,T2), (S3, T3) & 5.85 \\
10 & Partnership with local communities (S3,T4) & 5.80 \\
& Business partnership with private sector / business actors for investment and market & 5.78 \\
11 & development (W3, O3) & 5.55 \\
13 & Agribisniss training centre revitalization (S6, O6) & 5.52 \\
14 & Good Agriculture Practise (GAP) Implementation from on-farm to off-farm (S1, O2) \\
16 & Agro-tourism \& edu-tourism development (S4, O3) & 5.47 \\
\hline
\end{tabular}

Source: Data Processing

The most attractive score in the matrix is recommended for determining the business development of the Tasikmalaya TP as well as choosing a future TP management organization. The study is concluded with encouragement for the local government to establish an independent and professional institution with application of aggressive business strategies.

\section{Conclusion}

The current condition of the Tasikmalaya TP is that it has five core businesses and its mission is to become a center for dissemination, technology transfer, and agribusiness incubator. The TP is present in quadrant I by SWOT analysis, recommending the use of aggressive strategies such as market penetration and product development. Market penetration can be performed by intensive promotion, while product development can be implemented by agribusiness incubator revitalization or the development of agro- tourism and edu-tourism on the site.

There are four future management options and independent management is considered as the most appropriate and recommended exit strategy. It may become a Regionally-Owned Enterprise (BUMD) or have a hybrid management. One of the success stories in Techno Park hybrid management is that of the Samosir Techno Park. The role of the future management of the Tasikmalaya TP should be more supported by middle- to long-term strategies and a well prepared legal system.

As legal system preparation for a BUMD establishment takes a couple of years, it is recommended to apply a transitional management for Tasikmalaya TP in 2020 and 2021. When a Regional Regulation (Peraturan Daerah/Perda) for the establishment of the BUMD Tasikmalaya TP is proposed to be approved by the local parliament, the local budget for the most appropriate OPD for taking over the TP management would be needed in the transitional years. Moreover, revision of the Strategic Plan (Renstra SKPD) and annual work plan (RKPD) of the OPD is concomitantly required.

\section{Acknowledgments}

This paper is based on a study funded by the district government budget in 2018. Data were collected and processed by a professional consultant company on behalf of the local government institution. We express gratitude to Mr. Sandi Nurzaman, Mr. Dedi Siswana, and Ms. Retno Dyah Pekerti as the consultant team.

\section{References}

Asmara, A. Y., Oktaviyanti, D., Alamsyah, P., \& Zulhamdani, M. (2018). Science-techno park and industrial policy in Indonesia. Scholars' Press.

Cardeal, N., \& Antonio, N. S. (2012). Valuable, rare, inimitable resources and organization (VRIO) resources or valuable, rare, inimitable resources (VRI) capabilities: What leads to competitive advantage? African Journal of Business Management 6(37), 10159-10170 
David, M. E., David, F. R., \& David, F. R. (2017). The quantitative strategic planning matrix: a new marketing tool. Journal of Strategic Marketing, 25(4), 342-352.Enright, M. (2001). Approaches to market orientation and new product development in smaller enterprises: a proposal for a context-rich interpretive framework. Journal of Strategic Marketing, 9(4), 301-313.

Glaister, K. W., \& Falshaw, J. R. (1999). Strategic planning: still going strong?. Long Range Planning, 32(1), 107-116.

Greenley, G. E. (1994). Strategic planning and company performance: an appraisal of the empirical evidence. Scandinavian Journal of management, 10(4), 383-396.

Gupta, A. (2013). Environment \& PEST analysis: an approach to the external business environment. International Journal of Modern Social Sciences, 2(1), 34-43.

Helms, M. M., \& Nixon, J. (2010). Exploring SWOT analysis-where are we now?. Journal of strategy and management.

Kangas, J., Kurttila, M., Kajanus, M., \& Kangas, A. (2003). Evaluating the management strategies of a forestland estate - the SOS approach. Journal of environmental management, 69(4), 349-358.

Krzyżanowska, M., \& Tkaczyk, J. (2015). Redefining products as a positioning strategy: A case of the partnership for health. International Journal of Management Cases, 17, 81-97.

Kusharsanto, Z. S., \& Pradita, L. (2016). The important role of science and technology park towards Indonesia as a highly competitive and innovative nation. Procedia-Social and Behavioral Sciences, 227, 545-552.

Pickton, D. W., \& Wright, S. (1998). What's swot in strategic analysis?. Strategic change, 7(2), 101-109.

Piercy, N. F., \& Lane, N. (2009). Strategic customer management: Strategizing the sales organization. OUP Oxford.

Porter, M. E. (2001). The value chain and competitive advantage. Understanding Business Processes, 5066.

Porter, M. E. (2008). The five competitive forces that shape strategy. Harvard business review, 86(1), 2540. 